Historia Slavorum Occidentis

2018, nr 1 (16)

ISSN 2084-1213

DOI: $10.15804 /$ hso180102

Artur Makowski (Poznań)

\title{
Ludność Pleszewa w latach 1751-1793 w świetle ksiąg metrykalnych
}

Słowa kluczowe: Pleszew, demografia, XVIII w., księga metrykalna, miasto

Keywords: Pleszew, demography, $18^{\text {th }}$ century, birth certificate register, city

\begin{abstract}
Pleszew's population in 1751-1793. The research has been based on birth certificate registers as well as city records from the time in question which provide collective information on the demographic phenomena at work.
\end{abstract}

W pejzażu urbanistycznym dawnej Rzeczypospolitej dominowały małe miasta. Niniejszy artykuł jest próbą dokonania analizy populacji niewielkiego wielkopolskiego miasta Pleszewa, w okresie 1751-1793, na podstawie dokumentacji metrykalnej zachowanej w zasobie Archiwum Archidiecezjalnego w Gnieźnie, z uwzględnieniem niezbędnych źródeł z zachowanych akt miejskich pleszewskich z tego okresu. Płynące z niniejszych ustaleń wnioski mogą być przyczynkiem do szerszych badań nad przemianami ludnościowymi na ziemiach polskich w drugiej połowie XVIII stulecia, przed upadkiem szlacheckiej Rzeczypospolitej. Przegląd stanu badań nad ludnością miejską w dawnej Polsce pokazuje, że wielu historyków podejmowało prace nad tymi zagadnieniami. Trzeba jednak odnotować brak publikacji dotyczących demografii miasteczek Wielkopolski właściwej w XVIII w. Opracowania poświęcano innym regionom Rzeczypospolitej (m.in. publikacja Andrzeja Borzyszkowskiego Ludność Chojnic w potowie XVIII w., w której autor przedstawia stan zaludnienia miasta oraz strukturę zawo- 
dową i społeczną jego mieszkańców) ${ }^{1}$, albo skupiano się nad innym zasięgiem badanej społeczności, np. większe miasto (Kazimierz Mik zbadał ruch naturalny ludności i stan zaludnienia Krakowa w drugiej połowie XVIII w. na podstawie rejestracji chrztów, ślubów i zgonów ${ }^{2}$; badania Mieczysława Kędelskiego nad rozwojem demograficznym Poznania) ${ }^{3}$, parafia (Marek Górny na podstawie rejestracji metrykalnej przeprowadził badania nad ruchem naturalnym w parafii Szaradowo, liczącej 346 mieszkańców ${ }^{4}$; Emilia Brodnicka przedstawiła w swojej publikacji stan ludności i jego zmiany wywołane przez urodzenia i zgony w parafii Wieleń nad Notecią w latach $1760-1800^{5}$; badania Piotra Bokoty nad społecznością parafii św. Jana we Włocławku opierające się na wykorzystaniu ksiąg metrykalnych) ${ }^{6}$. Ponadto problem rekonstrukcji rodzin został poruszony przez Stanisława Borowskiego na przykładzie mikroregionu Czacz w drugiej części jego monografii ludnościowej ${ }^{7}$. Jak widać z powyższego przeglądu stanu badań nad problematyką demograficzną miast w XVIII w., ruch naturalny ludności zwykle przedstawiano na przykładzie parafii.

Księgi zawierające wykazy chrztów, ślubów i zgonów, prowadzone przez władze kościelne, określane są w Polsce mianem metryk ${ }^{8}$. W Kościele katolickim kwestia ewidencji wiernych została uregulowana w 1563 r. decyzją soboru trydenckiego, a następnie rozwinięta przez papieża Pawła V w Rituale Romanum z 1614 r. - księdze liturgicznej, w której zawierały się przepisy dotyczące administracji, sakramentów

1 A. Borzyszkowski, Ludność Chojnic w połowie XVIII w., Przeszłość Demograficzna Polski 7 (1975).

2 K. Mik, Ruch naturalny i rozwój zaludnienia Krakowa w drugiej połowie XVIII w., Przeszłość Demograficzna Polski 2 (1968).

3 M. Kędelski, Rozwój demograficzny Poznania w XVIII i na początku XIX wieku, Poznań 1992.

4 M. Górny, Rejestracja metrykalna parafii Szaradowo z XVIII wieku, Przeszłość Demograficzna Polski 18 (1990).

5 E. Brodnicka, Ludność parafii Wieleń nad Notecia w drugiej połowie XVIII w., Przeszłość Demograficzna Polski 2 (1968).

6 P. Bokota, Księgi metrykalne parafii św. Jana we Włoctawku jako źródto do badań nad miejscowa społecznością do końca XVIII wieku, Przeszłość Demograficzna Polski 20 (1997).

7 S. Borowski, Prawdopodobieństwa powiększenia rodziny w mikroregionie Czacz od XVII do XX wieku, Przeszłość Demograficzna Polski 10 (1978).

8 K. Dobrowolski, Znaczenie metryk kościelnych dla badań naukowych, Rocznik Towarzystwa Heraldycznego 5 (1920), s. 90; R. Kotecki, Rejestracja metrykalna wiernych w świetle potrydenckiego ustawodawstwa Kościoła katolickiego, Nasza Przeszłość. Studia z Dziejów Kościoła i Kultury Katolickiej w Polsce 112 (2009), s. 141-142; w sprawie znaczenia etymologicznego słowa „metryka” zob. J. Kurpas, Poczatki ksiag metrykalnych, Archiwa. Biblioteki i Muzea Kościelne 2 (1961), s. 6-9. 
i spełniania niektórych czynności kościelnych w kościołach parafialnych. Przeznaczono ją do użytku wszystkich duszpasterzy całego Kościoła katolickiego9. Od XVII w. prowadzenie metryk stało się w świecie katolickim ogólną zasadą ${ }^{10}$. Wymóg rejestracji metrykalnej wiernych $\mathrm{w}$ archidiecezji gnieźnieńskiej niewątpliwie zaszczepił prymas i arcybiskup Stanisław Karnkowski, który od 1581 r. kontynuował w Gnieźnie aktywną działalność legislacyjną, zapoczątkowaną jeszcze w diecezji włocławskiej ${ }^{11}$. Troskę o księgi metrykalne nakazywały ustawy synodu żmudzkiego z 1752 r. Zalecały one, by dawne księgi metrykalne były odsyłane do archiwum diecezjalnego. Kwestię przechowywania metryk przedstawił synod lwowski z $1765 \mathrm{r}$. Niejednokrotnie ustawodawca zwracał uwagę na skrupulatne prowadzenie ksiąg, obwarowując nakaz karą pieniężną. Biskupi podawali także szczegółowe wskazania odnośnie prowadzenia poszczególnych metryk ${ }^{12}$.

Podczas badania wartości źródłowej ksiąg metrykalnych parafii Pleszew z lat 1751-1793 zwrócono uwagę na kilka ważnych kwestii. Księgi są solidnie oprawione. Zasadniczo zachowana jest ciągłość chronologiczna; sporadycznie występują przesunięcia kolejności wpisów (późniejsze uzupełnianie wpisów). Kaligrafowano tytuły, stosowano roczne nadpisy, bardzo rzadko występują nieczytelne zapisy. Często występują karty z pustymi okienkami rezerwowanymi na akty ostatecznie nie wpisane. $\mathrm{W}$ kwestii stosowania datacji często powtarzano formulę ipso die ut supra zamiast wpisywania dat. Sporządzano luźne zapiski z danymi personalnymi, stanowiące podstawę późniejszego wpisu w księdze metrykalnej ${ }^{13}$. Osoby dokonujące

9 J. Hochleitner, Warmińskie nowożytne księgi chrztów jako źródło historyczne, Echa Przeszłości 2 (2001), s. 139; M. Fulman, Rytuat rzymski a piotrkowski. Studyum prawno-liturgiczne, Kraków 1896, s. 22; w kwestii postanowień soboru trydenckiego o księgach metrykalnych zob. R. Kotecki, Rejestracja metrykalna, s. 147; M. Różański, Akta metrykalne w prawodawstwie polskim, Archiwariusz. Biuletyn Archiwum Archidiecezjalnego w Poznaniu 1 (2005), s. 133; J. Kurpas, Początki ksiąg, s. 21-25; T. Moskal, Historia ksiąg metrykalnych kościoła katolickiego na ziemiach polskich, Archiwariusz. Biuletyn Archiwum Archidiecezjalnego w Poznaniu 1 (2005), s. 59-62.

10 K. Dobrowolski, Znaczenie metryk, s. 91.

11 R. Kotecki, Rejestracja metrykalna, s. 158; w kwestii upowszechnienia obowiązku prowadzenia metryk parafialnych zob. B. Kumor, Metryki parafialne w archiwach diecezjalnych, Kwartalnik Historii Kultury Materialnej 14 (1966), s. 65-68; C. Kuklo, Demografia Rzeczypospolitej przedrozbiorowej, Warszawa 2009, s. 91-95; P. Bokota, Księgi metrykalne, s. 95.

12 T. Moskal, Historia ksiag metrykalnych, s. 62-66.

$13 \mathrm{Z}$ powodu tej techniki rejestracji pewna liczba ochrzczonych mogła nie zostać wpisana do ksiąg metrykalnych, np. w skutek zwykłego zapomnienia wywołanego pośpiechem związanym $\mathrm{z}$ innymi obowiązkami duszpasterskimi. 
wpisów cechowała staranność i sumienność. Zauważono także częste zmiany pisma i atramentu. W prowadzeniu rejestracji występują przerwy. Stosunkowo krótka jest przerwa w księgach chrztów: marzec - kwiecień 1782 r., zdecydowanie większe luki odnotować można w księgach małżeństw: sierpień - grudzień 1767 r., marzec 1768 r. - czerwiec 1769 r., luty 1772 r. - styczeń 1773 r. Takie przerwy mają niewątpliwy wpływ na ostateczne wyniki obliczeń. Rejestracja podlegała kontroli przez wizytatorów parafii w następujących latach: księgi chrztów: 1755, 1761, 1782, 1786; księgi ślubów: 1755, 1761, 1782, 1786; księgi zamarłych: 1755, 1761, 1782, 1786 ${ }^{14}$. W badanym okresie w parafii Pleszew nie prowadzono ksiąg Status animarum ${ }^{15}$.

Księgi metrykalne w parafii pleszewskiej prowadzono od drugiej połowy XVII w. Ich stan zachowania przedstawia się następująco: libri baptisatorum obejmują lata: 1652-1692, 1743-1782, 1782-1797; libri copulatorum: 1732-1735, 1741-1772, 1773-1796; libri mortuorum: 1735-1772, 1772-1796. Dysponujemy zatem pełnym zakresem materiału źródłowego, który jest niezbędny do zbadania podjętego tematu. Przydatność pleszewskich ksiąg metrykalnych dla badań historycznych jest niewątpliwie bardzo wysoka. Cechuje je mała zmienność treści poszczególnych zapisów. Proces tworzenia ksiąg metrykalnych oraz ich przechowywanie znajdowały się pod kontrolą instytucji Kościoła katolickiego, co jeszcze bardziej podnosiło jakość tych źróde ${ }^{16}$.

Decyzją Sejmu Wielkiego nałożono na proboszczów parafii obowiązek corocznego sporządzania spisów parafialnych i odsyłania ich właściwym Komisjom Porządkowym Cywilno-Wojskowym. Tego rodzaju ujęcia statystyczne nie występują w parafii pleszewskiej ${ }^{17}$.

Pleszew wraz z przyległymi wsiami należał do kategorii dóbr prywatnych i był własnością szlachecką. Jeszcze w pierwszej połowie XVIII w. miasteczko przeszło jako posag z rąk dotychczasowych posiadaczy Zaleskich do Radomickich. Od 1728 r.

14 W kwestii początków wizytacji kościelnych na ziemiach dawnej Rzeczypospolitej zob. B. Kumor, Przedrozbiorowe wizytacje kościelne jako źródło demograficzne, Przeszłość Demograficzna Polski 2 (1969).

15 W kwestii prowadzenia ksiąg Status animarum na ziemiach dawnej Rzeczypospolitej zob. Tenże, Księgi Status animarum w diecezjach polskich (do roku 1918), Przeszłość Demograficzna Polski 7 (1975).

16 T. Florczak, Księgi metrykalne jako źródło historyczne na przykładzie parafii skalmierzyckiej, Archiwariusz. Biuletyn Archiwum Archidiecezjalnego w Poznaniu 1 (2005), s. 108-109.

17 C. Kuklo, Kobieta samotna w społeczeństwie miejskim u schytku szlacheckiej Rzeczypospolitej. Studium demograficzno-spoteczne, Białystok 1998, s. 39; tenże, Społeczno-demograficzny cykl życia cztowieka w mieście staropolskim u schytku XVIII w., Roczniki Dziejów Społecznych i Gospodarczych 62 (2002), s. 90. 
znalazło się w posiadaniu Jerzego Felicjana Sapiehy starosty wilkowskiego i jego żony Katarzyny z Radomickich. W 1740 r. owdowiały już Sapieha przekazał całe swoje dobra wielkopolskie, w tym Pleszew z przyległościami w ręce swej jedynej córki Marii i jej przyszłego męża Ignacego Koźmińskiego starosty wschowskiego ${ }^{18}$. Po śmierci Koźmińskiego w 1757 r. Marianna z Sapiehów wyszła w 1760 r. ponownie za mąż, za Ludwika Dąmbskiego starostę inowrocławskiego i gniewkowskiego, późniejszego wojewodę brzeskiego-kujawskiego, z którym ostatecznie się rozwiodła. Majątek pleszewski wraz z innymi dobrami przekazała w 1782 r. swej córce z pierwszego małżeństwa Ludwice Koźmińskiej, pozostającej już w separacji z pierwszym mężem, podkomorzym kaliskim Franciszkiem Ksawerym Sokolnickim. Ludwika, już po śmierci męża, na przełomie 1783 i 1784 r. sprzedała dobra pleszewskie (zapewne zadłużone) za 450 tys. zł Makaremu Gorzeńskiemu podkomorzemu J.K.M. ${ }^{19}$, którego niebawem poślubiła. Małżeństwo to również nie trwało długo i zostało unieważnione - Gorzeński już około 1790 r. ponownie się ożenit ${ }^{20}$. W wyniku bliżej nieznanych rozliczeń Ludwika z Koźmińskich pozostała jednak właścicielką Pleszewa aż do 1807 r., gdy sprzedała miasteczko w ręce Taczanowskich ${ }^{21}$. Co interesujące, Pleszew przez większość lat w badanym okresie pozostawał w zarządzie kobiet, które wnosząc dobra pleszewskie w posagu, zarządzały nim bądź pozostając w separacji, bądź jako wdowy. Oczywiście, podobnie jak w przypadku innych majętności szlacheckich, Pleszew z przyległościami był oddawany w krótkoterminowe dzierżawy ${ }^{22}$.

Jego ustrój nie odbiegał od szeroko przyjętych na ziemiach polskich rozwiązań i opierał się na funkcjonowaniu obok siebie dwóch odrębnych organów władzy. $\mathrm{Z}$ jednej strony był to odgrywający coraz mniejszą rolę wójt z ławą, z drugiej burmistrz i rada miejska. Pleszew był miasteczkiem o charakterze rolniczo-rzemieślniczym. Przodował w hodowli świń i owiec, a najbardziej rozwiniętymi cechami były: szewski i krawiecki. Produkcja rzemieślnicza nastawiona była na obsługę rynku lokalnego ${ }^{23}$. Znaczącą rolę odgrywały też w Pleszewie cechy rzeźnicki i piwowarski. Browarów było dużo, lecz wszystkie produkowały na potrzeby lokalne. Sukiennicy

18 Teki Dworzaczka, Archiwum Państwowe w Poznaniu (dalej APP), Gr. Wschowa 211, k. 37v. Kontrakt małżeński spisano w Wieluniu 24 II 1740 r. - przekazanie dóbr za spłatę długów Sapiehy. Ślub ostatecznie zawarto w Żerkowie, 19 II 1742 r.

19 Teki Dworzaczka, APP, Gr. Kalisz 438, k. 7.

20 A. Boniecki, Herbarz polski, t. 3, Warszawa 1903, s. 299.

21 S. Małyszko, Dziedzice Pleszewa, Rocznik Pleszewski (2007), s. 66-67.

22 Tenże, s. 66.

23 Dzieje Pleszewa, red. M. Drozdowski, Kalisz 1989, s. 53, 55-57, 61. 
i płóciennicy byli kolejną liczącą się w Pleszewie grupą rzemieślniczą. Ich wyroby znajdowały zbyt w całym okręgu kaliskim. W okolicach miasta znajdowały się bogate pokłady białej gliny będącej znakomitym surowcem do produkcji garncarskiej. Na tym surowcu oraz na jakości wyrobów opierał swoją opinię cech garncarzy. Ważną rolę w życiu gospodarczym miasta odgrywały cotygodniowe targi oraz coraz częstsze jarmarki. Od 1783 r. można już było w Pleszewie odbywać 13 jarmarków²4.

Tabela 1. Rejestracja ruchu naturalnego ludności w Pleszewie w latach 1751-1793

\begin{tabular}{|c|c|c|c|c|c|}
\hline Lata & $\begin{array}{c}\text { Średnia liczba } \\
\text { urodzeń }\end{array}$ & $\begin{array}{c}\text { Średnia liczba zawartych } \\
\text { małzeństw }\end{array}$ & $\begin{array}{c}\text { Średnia liczba } \\
\text { zgonów }\end{array}$ & $\begin{array}{c}\text { Współczynnik } \\
\text { U/M }\end{array}$ & $\begin{array}{c}\text { Współczynnik } \\
\text { U/Zg }\end{array}$ \\
\hline $1751-1760$ & 69,2 & 14,7 & 48,5 & 4,7 & 1,4 \\
\hline $1761-1770$ & 73,5 & $12,4^{\mathrm{a}}$ & 46,1 & 5,9 & 1,6 \\
\hline $1771-1780$ & 63,4 & $13,2^{\mathrm{b}}$ & 32,9 & 4,8 & 1,9 \\
\hline $1781-1790$ & 96,4 & 18,0 & 65,5 & 5,4 & 1,5 \\
\hline $1791-1793$ & 107,7 & 21,3 & 64,7 & 5,1 & 1,7 \\
\hline
\end{tabular}

Opracowano na podstawie: AAG, Archiwum parafii Pleszew, 20a (Liber copulatorum 1741-1772); AAG, Archiwum parafii Pleszew, 10 (Liber copulatorum 1772-1796); AAG, Archiwum parafii Pleszew, 2 (Liber baptisatorum 1743-1782); AAG, Archiwum parafii Pleszew, 3 (Liber baptisatorum 1782-1797); AAG, Archiwum parafii Pleszew, 15 (Liber mortuorum 1735-1772); AAG, Archiwum parafii Pleszew, 10 (Liber mortuorum 1772-1796). Wszystkie pozostałe tabele i wykresy zostały opracowane na podstawie wyżej wymienionych ksiąg.

a Przerwa w rejestracji małżeństw w okresach: sierpień-grudzień 1767 i marzec-czerwiec 1769.

${ }^{\mathrm{b}}$ Przerwa w prowadzeniu rejestracji małżeństw od lutego 1772 do stycznia 1773.

Parafia pleszewska w omawianym okresie była położona w obrębie administracyjnym archidiecezji gnieźnieńskiej, na terenie dekanatu pleszewskiego. W dniu $21 \mathrm{II} 1755 \mathrm{r}^{25}$ przeprowadził jej wizytację generalną na polecenie arcybiskupa Adama Komorowskiego archidiakon kaliski Aleksander Gembarth. Według protokołu wizytacyjnego granice parafii obejmowały: miasto Pleszew, folwarki Malinie i Łasew oraz pięć młynów wodnych: Śmieja, Robak, Kobyłka, Foluszny i Borowy Łapski ${ }^{26}$. Pod koniec XVIII w. ewangelicy mieszkający w Pleszewie i okolicach podejmowali działania, by ustanowić parafię. W 1795 r. zaczęło się jej formalne organizowanie ${ }^{27}$.

24 J. Piasecki, Dzieje rzemiosła pleszewskiego, Pleszew 1993, s. 28, 39.

25 Liber copulatorum 1741-1772, Archiwum Archidiecezjalne w Gnieźnie (dalej AAG), Archiwum parafii Pleszew, 20a, k. 25v-26.

26 W. Zientarski, Zarys dziejów Parafi pod wezwaniem Ścięcia św. Jana Chrzciciela w Pleszewie, Pleszew 1994, s. 12, 14.

27 O. Kiec, Zarys dziejów ewangelickiej parafii w Pleszewie 1794-1945, Rocznik Pleszewski (2010), s. 159-161. 
W ciągu badanego okresu w Pleszewie urzędowało dwóch proboszczów. W latach $1750-1771^{28}$ funkcję tę pełnił kanonik chocki ks. Ludwik Pełka ${ }^{29}$. Władza duchowna mianowała nowym proboszczem pleszewskim ks. Ignacego Sczanieckiego, który rozpoczął swoją działalność 9 VI 1773 r. (proboszczem był do końca omawianego okresu) ${ }^{30}$.

Podstawowy współczynnik U/M powinien kształtować się w granicach pięciu chrztów na jedno zawarte małżeństwo ${ }^{31}$. Współczynnik U/M pozwala obliczyć (z pewnymi zastrzeżeniami) dzietność przeciętnej rodziny w badanym okresie ${ }^{32}$. Na podstawie danych z tabeli 1. można stwierdzić, że w ciągu badanego okresu w przeciętnej rodzinie pleszewskiej rodziło się pięcioro dzieci (jedynie w latach 1766-1770 liczba ta wzrasta do sześciu). Przy określaniu liczebności dzieci należy mieć na uwadze współczynnik umieralności dzieci (tabela 9), który wynosił 29\% urodzonych. Otrzymany współczynnik urodzeń na jedno nowo zawarte małżeństwo zmniejszony o 29\% może być przyjęty jako określający liczbę dzieci w rodzinie ${ }^{33}$.

Generacje osób zawierających małżeństwo i rodzących dzieci są zasadniczo różne. Ponadto krótkookresowe liczby urodzeń i ślubów silnie zależą od bieżących struktur ludności ${ }^{34}$.

28 Ostatni wpis w księdze metrykalnej, informujący o udzieleniu ślubu przez Pełkę, pochodzi z 14 VI 1773 r., zob. Liber copulatorum 1772-1796, AAG, Archiwum parafii Pleszew, 10, k. 51v. 29 Urodził się w 1706 r. Wykształcenie zdobył u jezuitów. W 1734 r. otrzymał święcenia kapłańskie i objął probostwo pleszewskie, piastował godność kanonika w kapitule w Choczu. pełnił również funkcję dziekana dekanatu pleszewskiego. O objęciu w 1763 r. godności kanonika katedralnego poznańskiego (o której pisał W. Zientarski, Zarys dziejów Parafii, s. 11), brak informacji w zestawieniu R. Weimanna, Receptiones seu installationes [...], Roczniki Towarzystwa Przyjaciół Nauk Poznańskiego, 35 (1908). O pełnieniu przez Pełkę godności kanonika poznańskiego, świadczy dopisek przy dacie jego zgonu w księdze zmarlych: canonicus Posnaniensis (Liber copulatorum 1772-1796, AAG, Archiwum parafii Pleszew, 10, k. 11) - mogło chodzić o kapitułę kolegiaty Najświętszej Maryi Panny na Tumie lub kapitułę kolegiaty Marii Magdaleny w Poznaniu. Utrudzony chorobą, zrezygnował w 1771 r. z prepozytury pleszewskiej, pozostał jednak w parafii, pełniąc obowiązki altarysty. Zmarł 3 XII 1782 r.; zob. W. Zientarski, Zarys dziejów Parafii, s. 11; Liber mortuorum 1772-1796, AAG, Archiwum parafii Pleszew, 10, k.11. $30 \quad 8$ I 1774 r. Ignacy Sczaniecki po raz pierwszy został określony jako prepositus Plessevienis w księdze zaślubionych (tamże, 10, k. 51v); W. Zientarski, Zarys dziejów Parafii, s. 15.

31 I. Gieysztorowa, Niebezpieczeństwa metodyczne polskich badań metrykalnych XVII-XVIII wieku, Kwartalnik Historii Kultury Materialnej,19 (1974), s. 592.

32 A. Szczypiorski, Badania ksiag metrykalnych a obliczenia ludności Polski w wieku XVII-XVIII, Kwartalnik Historii Kultury Materialnej 10 (1962), s. 70.

33 Tenże, s. 73.

34 J. Paradysz, Wspótczesna demografia regionalna i kilka wniosków z niej wyptywajacych dla innych badań w mikroskali, Przeszłość Demograficzna Polski 26 (2005), s. 184-185. 
Księgi ślubów były najstaranniej i najpełniej prowadzone. Przywiązywano do nich największą wagę w trosce o legalność potomstwa. Legalnego pochodzenia wymagano od osób ubiegających się o przyjęcie do prawa miejskiego ${ }^{35}$. W myśl postanowień soboru trydenckiego proboszcz zobowiązany był do posiadania księgi, w której miał odnotowywać imiona małżonków i świadków oraz dzień i miejsce zawarcia małżeństwa; ponadto mial ją starannie przechowywać ${ }^{36}$. Oprócz wymienionych informacji, w pleszewskich libri copulatorum rejestrowano imię i nazwisko osoby udzielającej sakramentu, ewentualny fakt wdowieństwa nowożeńców, pełnioną funkcję publiczną, zawód (zwłaszcza u świadków) oraz tytulaturę stosowaną w społeczeństwie stanowym epoki feudalnej (dominują predykaty famatus, honestus, laboriosus). Podobną zawartość informacyjną mają akta metrykalne parafii św. Jana we Włocławku ${ }^{37}$.

Wykres 1. Liczba ślubów w Pleszewie w latach 1751-1793

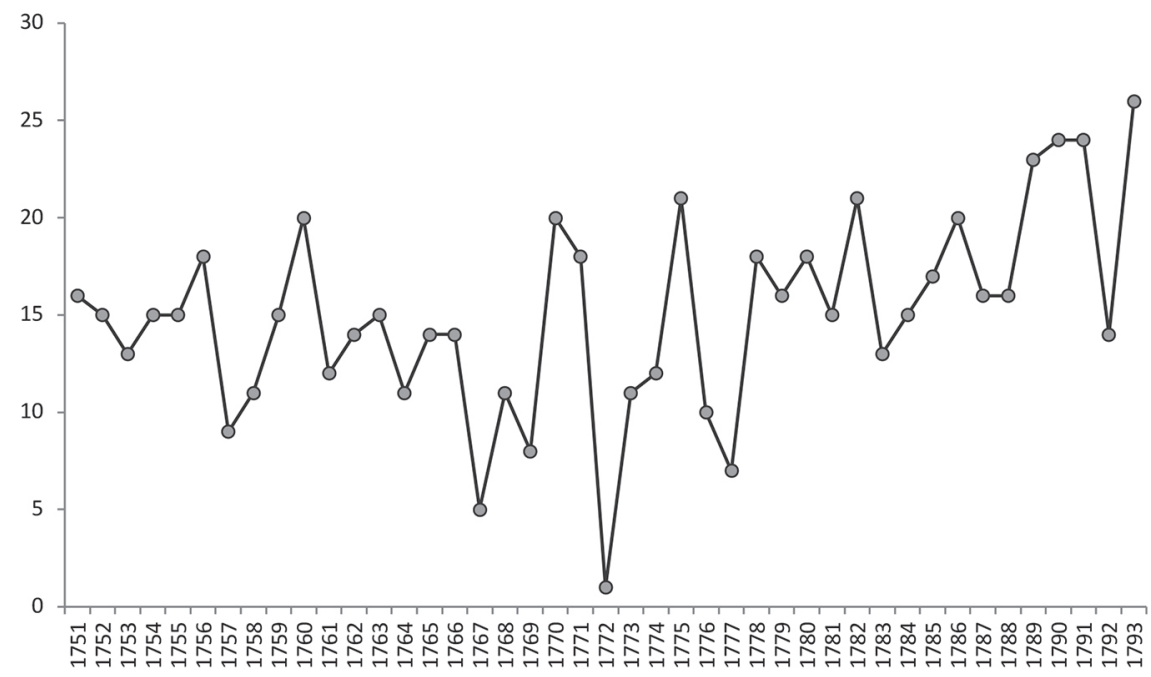

Sakramentu małżeństwa udzielał proboszcz. Jeśli czynił to inny kapłan, stosowano formułę: (imię i nazwisko kapłana udzielającego ślubu) ex commissione et licentia (imię i nazwisko proboszcza) $)^{38}$.

35 I. Gieysztorowa, Badania demograficzne na podstawie metryk parafialnych, Kwartalnik Historii Kultury Materialnej 10 (1962), s. 111; M. Kędelski, Rozwój demograficzny Poznania, s. 28-30.

36 Dokumenty soborów powszechnych, wyd. A. Baron, H. Pietras, Kraków 2004, t. 4, s. 723.

37 P. Bokota, Księgi metrykalne, s. 96.

38 Rozporządzenia trydenckie nakazywały, aby błogosławieństwo było udzielane przez wła- 
Metryki ułatwiały kontrolę stosowania się parafian do przepisów kościelnych. Pozwalały stwierdzić prawność bądź nielegalność małżeństwa, a także zauważyć istnienie kanonicznej przeszkody w zawarciu małżeństwa ${ }^{39}$. Poniższy wykres pokazuje dane o liczbie ślubów zawartych $\mathrm{w}$ danym roku w ciągu badanego okresu.

W latach 1751-1793 zawarto w parafii pleszewskiej 647 ślubów. Najwięcej małżeństw zarejestrowano w 1793 r. (26), a najmniej w 1772 r. (1). Nasuwa się pytanie czy nie wystąpiły procesy imigracyjne, które wpłynęłyby na zwiększenie liczby zapisów w 1793 r. Odpowiedzi na to pytanie należy szukać w związku z napływem osadników olęderskich, którzy w tym czasie przybywają do Pleszewa i najbliższych okolic ${ }^{40} .11$ VII 1773 r. zarejestrowano w Pleszewie pierwsze w badanym okresie małżeństwo z osobą pochodzenia pruskiego ${ }^{41}$, później, do końca 1793 r. zawarto już 34 małżeństwa z pruskimi przybyszami, a największe nasilenie tego zjawiska przypada na lata $1785-1793^{42}$. Ponadto należy zwrócić uwagę na pojawienie się nowych nazwisk (pochodzenia pruskiego) w księgach zarówno metrykalnych, jak i miejskich. Spadek liczby ślubów w 1772 r. spowodowany był prawdopodobnie przerwą w prowadzeniu rejestracji bądź wydarzeniami politycznymi rozgrywającymi się w tym czasie na terenie Rzeczypospolitej. Nie występują żadne informacje dotyczące pojawienia się jakiejś epidemii w tym czasie. Ponadto należy zauważyć, że w tym czasie miała miejsca zmiana proboszczów w parafii, co również może mieć wpływ na zaburzenie procesu rejestracji. Średnia liczba ślubów rocznie wynosiła 15 . Z analizy tabeli wynika, że liczba małżeństw wzrasta od $1778 \mathrm{r}$.

Kolejnym elementem jest sezonowość miesięczna zawierania małżeństw ${ }^{43}$.

Tabela 2. Sezonowość miesięczna zawierania małżeństw w Pleszewie w okresie 1751-1793.

\begin{tabular}{|c|c|c|c|c|c|c|c|c|c|c|c|c|c|}
\hline \multirow{2}{*}{ Wyszczególnienie } & \multirow{2}{*}{ Ogółem } & \multicolumn{12}{|c|}{ Miesiąc zawarcia małżeństwa } \\
\hline & & I & II & III & IV & $\mathrm{V}$ & VI & VII & VIII & IX & $\mathrm{X}$ & XI & XII \\
\hline Liczby bezwzględne & 647 & 171 & 258 & 12 & 10 & 27 & 25 & 25 & 17 & 9 & 30 & 63 & - \\
\hline Wskaźnik sezonowości & 1200 & 304 & 503 & 21 & 18 & 48 & 46 & 45 & 30 & 16 & 53 & 116 & - \\
\hline
\end{tabular}

ściwego proboszcza, natomiast pozwolenie na udzielenie takiego błogosławieństwa mogło być udzielone innemu kapłanowi tylko przez samego proboszcza, albo biskupa ordynariusza; zob. Dokumenty soborów powszechnych, s. 723.

39 K. Dobrowolski, Znaczenie metryk, s. 91.

40 W kwestii osadnictwa olęderskiego w Wielkopolsce zob. K. Korenda, Społeczność osad olęderskich w parafii Pszczew od XVIII do pierwszej połowy XIX wieku, Przeszłość Demograficzna Polski 26 (2005).

41 Liber copulatorum 1772-1796, AAG, Archiwum parafii Pleszew, 10, k. 51v.

42 Tamże, 10, k. 61v-74.

43 C. Kuklo, Demografia Rzeczypospolitej, s. 162. 
W małych miastach o charakterze rolniczym, małżeństwa zawierano najczęściej jesienią i zimą, po zakończeniu wielu wcześniejszych zajęć gospodarskich (orki, siewy) i zgromadzeniu odpowiednich zapasów żywności i niezbędnych funduszy. W Pleszewie najczęściej zawierano małżeństwa na zapusty, czyli w styczniu oraz w lutym, a także w listopadzie (63); w miesiącach letnich ludność była zabsorbowana pracą na roli i dopiero pod koniec roku dysponowała odpowiednimi środkami finansowymi, które umożliwiłyby zorganizowanie wesela czy zgromadzenie posagu. Ponadto ze względu na porę roku styczeń oraz luty były miesiącami krótszej pracy. Grudzień, jako okres adwentu, w zasadzie był wyłączony przez Kościół z uroczystości weselnych; w tym miesiącu nie zarejestrowano ani jednego ślubu ${ }^{44}$. Obowiązujące przepisy kościelne zabraniały wstępowania w związki małżeńskie także w okresie Wielkiego Postu.

Podobnie w parafii Wieleń nad Notecią istniała wyraźna sezonowość zawierania małżeństw. W latach 1760-1800 zanotowano tylko sześć ślubów w miesiącu marcu, tj. miesiącu Wielkiego Postu. Również w grudniu, tj. miesiącu Adwentu, nie zawierano małżeństw. Spośród innych miesięcy największą liczbę ślubów wykazywał styczeń, luty oraz listopad. Na sezonowość ślubów miały wpływ względy religijne i obyczajowe ${ }^{45}$.

Tabela 3. Śluby udzielone w parafii Pleszew w okresie 1751-1793 według stanu cywilnego nowożeńców

\begin{tabular}{|l|c|c|}
\hline \multicolumn{1}{|c|}{ Rodzaj związku } & Liczby bezwzględne & Liczby względne [\%] \\
\hline kawaler-panna & 564 & 87 \\
\hline kawaler-wdowa & 43 & 7 \\
\hline wdowiec-panna & 25 & 4 \\
\hline wdowiec-wdowa & 15 & 100 \\
\hline Razem & 647 & 2 \\
\hline
\end{tabular}

Księgi zaślubionych zawierają również wpisy o wdowieństwie nowożeńców. W latach 1751-1793 liczba wdów, które ponownie zawarly związek małżeński wyniosła 58, wdowców zaś 40. Jeżeli kobietę określono mianem vidua, to jej nazwisko kończyło się na - owa.

Do rozpadów małżeństw dochodziło wyłącznie z przyczyn naturalnych, za sprawą śmierci jednego z małżonków.

44 Tenże, s. 298.

45 E. Brodnicka, Ludność parafii Wieleń, s. 210. 
Zarówno staropanieństwo, jak i starokawalerstwo nie było popularne. Wpływ na takie postępowanie miały zapewne chęć jak najszybszego założenia rodziny oraz doczekania się licznego potomstwa, co było łatwiejsze jeśli zawierało się ślub pomiędzy 20 a 30 rokiem życia. Liczna rodzina w społeczeństwach zamieszkujących miasteczka była bardzo istotną pomocą w prowadzeniu gospodarstwa rolnego, warsztatu rzemieślniczego lub działalności handlowej.

Małżonków określano predykatami wskazującymi na przynależność stanową, np. famatus, honestus, laboriosus, a w przypadku szlachty sporadycznie pojawiającej się w metrykaliach pleszewskich, również generosus czy nobilis. Dominowały małżeństwa zawierane w obrębie tego samego stanu, lecz zdarzały się wyjątki, np. ślub chłopa z mieszczką $(1755,1759 \text { oraz } 1775 \text { r. })^{46}$, ślub mieszczanina z chłopką (1782 oraz 1784 r. $)^{47}$. Do wpisów małżeństw chłopskich dodawano informację, że ślubujący jest osobą wolną i nie pozostaje w stosunku poddańczym (liberum non subditum $)^{48}$.

Ślubującego młodzieńca określano terminem iuvenis, natomiast dziewczynę virgo (łac. dziewica) lub pudica (łac. cnotliwa, czysta płciowo) - w większości przypadków towarzyszyło jej nazwisko zakończone na - ówna.

Osadnictwo olęderskie w najbliższej okolicy Pleszewa (wsie Ludwina, Zielona Łąka, Dobra Nadzieja), którego największe nasilenie przypada na lata 1785-1793, miało niewątpliwie wpływ na demografię miasteczka. Odsetek ślubów z pruskimi przybyszami wyniósł w tym okresie $18,6 \%$, co oznacza, że niemal w co piątym małżeństwie jednym z nupturientów był pruski osadnik. Pojawiają się też nowe imiona. Krótkie przedstawienie zagadnienia stanowi zachętę do podjęcia dalszych rozważań i dyskusji nad tym tematem.

Nowożeńcy rekrutowali swoich świadków z tej samej grupy społeczno-zawodowej i przeważnie z tej samej miejscowości. Świadkowie pochodzili także z elity społecznej: burmistrz, wiceburmistrz, wójt, rajcy, ławnicy, pisarz miejski, cechmistrzowie, a także właściciele pobliskich wsi. W przypadkach małżeństw chłopskich, świadkowie pochodzili zwykle również ze stanu chłopskiego. W badanym okresie świadkami wpisywanymi z imienia i nazwiska, zgodnie zapisami prawa, byli wyłącznie mężczyźni. W latach 1751-1772 ich liczba wynosiła od trzech do pięciu ${ }^{49}$.

\footnotetext{
46 Liber copulatorum 1741-1772, AAG, Archiwum parafii Pleszew, 20a, k. 26, 3; Liber copulatorum 1772-1796, AAG, Archiwum parafii Pleszew, 10, k. 53v.

47 Tamże, 10, k. 59, 60v.

48 Liber copulatorum 1741-1772, AAG, Archiwum parafii Pleszew, 20a, k. 27v.

49 Tamże.
} 
W latach 1773-1793 liczbę świadków ograniczono do dwóch ${ }^{50}$. Liczba świadków została sprecyzowana przez sobór trydencki.

W wielu sytuacjach nie wymieniano świadków z imienia i nazwiska, wpisywano jedynie, używając powtarzalnej formuły, że małżeństwo zostało zawarte w obecności mieszczan pleszewskich (in praesentia civium Plesseviensium, testis Plesseviensis) ${ }^{51}$. $\mathrm{W}$ przypadku, gdy byli oni pochodzenia pruskiego, zaznaczano, że są katolikami oraz wisywano miejsce zamieszkania, np. Holendrzy pleszewscy z Dobrej Nadziei.

Tabela 4. Liczba zawartych małżeństw z osobami pruskiego pochodzenia na tle ogólnej liczby ślubów w Pleszewie w latach 1785-1793

\begin{tabular}{|c|c|c|}
\hline Rok & Ogólna liczba zawartych małżeństw & Liczba zawartych małżeństw z osobami pruskiego pochodzenia \\
\hline 1785 & 17 & 3 \\
\hline 1786 & 20 & 4 \\
\hline 1787 & 16 & 4 \\
\hline 1788 & 16 & 5 \\
\hline 1789 & 23 & 4 \\
\hline 1790 & 24 & 6 \\
\hline 1791 & 24 & 3 \\
\hline 1792 & 14 & 1 \\
\hline 1793 & 26 & 3 \\
\hline
\end{tabular}

Księgi zaślubionych pozwalają odtworzyć ruchliwość terytorialną nowożeńców. Dominowały małżeństwa osób pochodzących z terenu parafii, a w dalszej kolejności przybyszów z pobliskich miejscowości. W omawianym okresie miało miejsce tylko jedno małżeństwo, w którym obydwoje nupturienci pochodzili spoza obrębu parafii pleszewskiej $(1757 \mathrm{r} \text {. })^{52}$. W pozostałych przypadkach przynajmniej jeden z nowożeńców pochodził z terenu parafii.

$\mathrm{Z}$ analizy danych zawartych $\mathrm{w}$ księgach metrykalnych badanego okresu wynika, że do Pleszewa częściej migrowali mężczyźni (47 przybyłych z innych ośrodków zawarło małżeństwo) niż kobiety ( 27 przybyłych z innych ośrodków zawarło małżeństwo). Nowożeńcy najczęściej napływali z miejscowości w obrębie $40 \mathrm{~km}$ od Pleszewa. Najdalej położone ośrodki, z których przybywali nowożeńcy do Pleszewa to: Kłobuck (135 km), Lwówek (126 km), Grodzisk (104 km), Buk (100 km), Skoki $(97 \mathrm{~km})$, Bojanowo $(75 \mathrm{~km})$, Gniezno $(72 \mathrm{~km})$ oraz Miejska Górka $(63 \mathrm{~km})$.

\footnotetext{
50 Liber copulatorum 1772-1796, AAG, Archiwum parafii Pleszew, 10.

51 Liber copulatorum 1741-1772, AAG, Archiwum parafii Pleszew, 20a, k. 25v, 45.

52 Tamże, AAG, 20a, k. 28v; określono ich jako inquilini - łac. dzierżawcy, czynszownicy.
} 
$\mathrm{W}$ omawianym okresie ${ }^{53}$ do klucza pleszewskiego należały następujące miejscowości: Pleszew, Malinie, Łasewo [Łasew], Baranówek, Baranowo [Baranów], Piekarzew [Piekarzewo] ${ }^{54}$. Według danych zawartych w tabeli 5 wynika, że 15 osób pochodzących z klucza pleszewskiego (nie licząc samego miasta Pleszew) zawarło małżeństwo: z Malinia: cztery, z Łasewa: pięć, z Baranówka: jedna, z Baranowa: cztery, z Piekarzewa: jedna.

Tabela 5. Liczba nowożeńców pochodzących spoza parafii Pleszew w okresie 1751-1793

\begin{tabular}{|c|c|c|}
\hline \multirow{2}{*}{ Miejscowość } & \multicolumn{2}{|c|}{ Pleć } \\
\hline & mężczyźni & kobiety \\
\hline Baranowo & 4 & - \\
\hline Baranówko & 1 & - \\
\hline Bojanowo & 1 & - \\
\hline Borek & 2 & 1 \\
\hline Borów & 1 & - \\
\hline Buk & 3 & 1 \\
\hline Cegielnia & - & 2 \\
\hline Chocz & 2 & 1 \\
\hline Cieśle & 1 & - \\
\hline Dobrzyca & 1 & - \\
\hline \begin{tabular}{|l|} 
Głogowo \\
\end{tabular} & - & 1 \\
\hline Gniezno & 1 & - \\
\hline \begin{tabular}{|l|} 
Grodzisk \\
\end{tabular} & 1 & - \\
\hline Jaraczewo & - & 1 \\
\hline Jarocin & - & 1 \\
\hline Kakawa & - & 1 \\
\hline Kalisz & 2 & - \\
\hline Kłobuck & 1 & - \\
\hline Kobylin & 2 & - \\
\hline Koźmin & - & 1 \\
\hline Krotoszyn & 2 & 2 \\
\hline Krzepica & 1 & - \\
\hline Lubinia & 2 & - \\
\hline Lwówek & 1 & - \\
\hline Easew & 2 & 3 \\
\hline Malinie & - & 4 \\
\hline Marszew & 1 & - \\
\hline
\end{tabular}

53 Informacje o kluczu pleszewskim pochodzą ze spisów inwentarzowych z lat 1748-1781.

54 Inwentarze dóbr szlacheckich powiatu kaliskiego, wyd. W. Rusiński, Wrocław 1955, t. I, s. 757 -759; Inwentarze, t. II, s. 59-63, 581-587; W. Rusiński, Inwentarze dóbr szlacheckich dawnego powiatu kaliskiego z lat 1776-1792, Rocznik Kaliski 15 (1982), s. 193-207. 


\begin{tabular}{|l|c|c|}
\hline Miejska Górka & 1 & 1 \\
\hline Molendino foluszne & 3 & 1 \\
\hline Nowa & 1 & - \\
\hline Piekarzew & 1 & - \\
\hline Pustkowie & - & 1 \\
\hline Pyzdry & - & 1 \\
\hline Raszewko & 1 & - \\
\hline Raszków & 1 & 1 \\
\hline Rychwał & - & 1 \\
\hline Skoki & 1 & - \\
\hline Słaboszewo & 1 & - \\
\hline Sobota & 1 & - \\
\hline Taczanów & - & 1 \\
\hline Tursko & 1 & - \\
\hline Witaszyce & 1 & - \\
\hline Zagórów & 1 & - \\
\hline Żerków & 1 & 1 \\
\hline Razem & 47 & 27 \\
\hline
\end{tabular}

Miejscem zawierania małżeństw był kościół farny w Pleszewie, a osobą, która zazwyczaj udzielała ślubu był proboszcz, choć zdarzały się sytuacje, kiedy czynił to inny duchowny ${ }^{55}$.

W Libri baptisatorum rejestrowano następujące informacje: imię i nazwisko udzielającego sakramentu, imię lub imiona dziecka z zaznaczeniem jego płci i legalności urodzenia, imiona rodziców oraz nazwisko ojca wraz z jego pochodzeniem społecznym (chłopów i uboższych mieszczan metryki określają na ogół tylko z imienia, czasem przezwiskiem), zawodem lub sprawowanym urzędem, miejsce zamieszkania rodziców, imiona i nazwiska rodziców chrzestnych wraz z ich pochodzeniem społecznym, zawodem, sprawowanym urzędem oraz miejscem zamieszkania ${ }^{56}$.

55 Na przykład: Paweł Śniegocki - wikariusz kościoła farnego w Pleszewie (Liber copulatorum 1741-1772, AAG, Archiwum parafii Pleszew, 20a, k. 23v), Józef Borecki - proboszcz z Lenartowic (tamże, k. 23v), Stanisław Burzyński - wikariusz z Gołuchowa (tamże, k. 25), Antoni Trzciński - prepozyt Kościoła Szpitalnego Św. Ducha w Pleszewie (tamże, k. 26), Franciszek Wolski - Ojciec Reformata z Chocza (tamże, k. 28), Mateusz Rychlewicz - wikariusz kościoła kolegiackiego w Kaliszu (tamże, k. 37), Stanisław Pawłowski - altarysta w kościele farnym (tamże, k. 36v).

56 Przykładowy wpis do księgi chrztów: Die 26ta, ego qui supra, baptisavit Margaretham Famatorum Caroli et Mariannae Kostrzewskich legitimorum coniugorum. Patrini Honestus Franciscus Adamkiewicz et Famata Catharina Rolińska. Omnes de Pleszew; zob. Liber baptisatorum 1782 -1797, AAG, Archiwum parafii Pleszew, 3, k. 27. 
Księgi chrztów nie rejestrowały daty urodzenia, gdyż nie wymagało tego ustawodawstwo synodalne z tego okresu. Należy zaznaczyć, że liczba chrztów nie była równa liczbie urodzeń. Jedną z przyczyn takiego stanu były na przykład koszta, które wiązały się z uroczystością chrztu, których najubożsi parafianie często nie byli w stanie ponieść. W sytuacji, gdy dziecko rokowało nikłą szansę na przeżycie, chrzest kościelny odkładano, nie chcąc narażać się na wydatki. Wątłym noworodkom z pewnością udzielano tzw. chrztu z wody ${ }^{57}$.

Tabela 6. Natężenie zawierania małżeństw w Pleszewie w latach 1771, 1789 i 1793

\begin{tabular}{|c|c|c|}
\hline Rok & Liczba ludności $^{a}$ & Współczynnik małżeństw [\%o] $^{\mathrm{a}}$ \\
\hline 1771 & $1000^{\mathrm{b}}$ & 18,0 \\
\hline 1789 & $1509^{\mathrm{c}}$ & 15,2 \\
\hline 1793 & $1254^{\mathrm{d}}$ & 20,7 \\
\hline
\end{tabular}

${ }^{a}$ Dysponujemy niewielką ilością materiału źródłowego dotyczącego liczby mieszkańców Pleszewa w omawianym okresie. Wiedza o rozmiarach i strukturze zaludnienia opiera się głównie na źródłach skarbowych (pierwszy spis ludności uchwalił Sejm Czteroletni 22 VI 1789 r.); zob. Irena Gieysztorowa, Od metryk do szacunków ludności, Kwartalnik Historii Kultury Materialnej, 12 (1964): 283-298; Irena Gieysztor, Wstęp do demografii staropolskiej (Warszawa: Państwowe Wydawnictwo Naukowe, 1976), 110-116.

${ }^{\mathrm{b}}$ Szacunkowa liczba mieszkańców w tym okresie to około 1000 osób; zob. Inwentarze, t. II, 582.

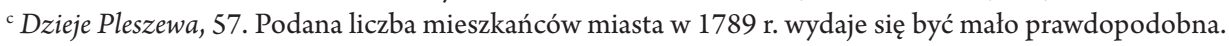
Po pierwsze: zbyt duży spadek liczby ludności do 1793 r. Po drugie: autor nie podaje źródła, z którego zaczerpnął te dane.

dJan Wąsicki, Opisy miast polskich z lat 1793-1794, cz. 2 (Poznań: Wydawnictwo Naukowe UAM, 1962), 761.

Wymogiem prawa kanonicznego było szybkie chrzczenie noworodków ${ }^{58}$. W nagłych i koniecznych wypadkach, zwłaszcza, gdy niemowlęciu groziło niebezpieczeń-

57 K. Korenda, Rejestracja metrykalna parafii Pszczew z XVII wieku, Przeszłość Demograficzna Polski 24 (2003), s. 48.

58 W czasach nowożytnych obawiano się śmierci niemowląt bez chrztu, gdyż wedle ówczesnych wyobrażeń dusze tych dzieci były skazane na wieczne potępienie; zob. J. Hochleitner, Warmińskie nowożytne księgi, s. 143. Prawdopodobnie część wcześnie zmarlych noworodków nie zaznała w ogóle chrztu kościelnego; zob. I. Gieysztorowa, Niebezpieczeństwa metodyczne, s. 584. Znaczącą rolę związaną z chrztem dzieci odgrywała również ofiara iura stolae, składana kapłanom między innymi za udzielane sakramentów. Zbyt wygórowane opłaty z tego tytułu mogły stać się przyczyną uchylania się ludności, zwłaszcza warstw niższych, od korzystania z posługi duszpasterskiej księży. B. Kumor, Przepisy prawne w sprawie chrztu dzieci w XVI-XVIII w., Przeszłość Demograficzna Polski. Materiały i Studia 9 (1976), s. 42. Według taksy wydanej w 1761 r. przez arcybiskupa gnieźnieńskiego Władysława Łubieńskiego, udzielenie chrztu winno być bezpłatne, chyba że osoby zainteresowane złożą dobrowolną ofiarę. W sprawie opłat iura stolae $\mathrm{w}$ archidiecezji gnieźnieńskiej zob. H. Karbownik, Ofiary iura stolae na ziemiach polskich w latach 1285-1918, Lublin 1995, s. 91-95. Stawki oplat w parafii pleszewskiej nie są jednak znane. 
stwo śmierci, udzielany był tzw. chrzest z wody ${ }^{59}$. Księgi zgonów uważa się za najmniej skrupulatnie prowadzone spośród wszystkich ksiąg metrykalnych. Przepisy soboru trydenckiego nie określały dokładnie, w którym dniu po urodzeniu dziecka należało je ochrzcić. W rozporządzeniach synodalnych Rzeczypospolitej określono termin chrztu do ósmego dnia po urodzeniu dziecka. W oparciu o zarządzenia kościelne, można zatem przesunąć datę urodzenia dziecka do ośmiu dni przed datę chrztu ${ }^{60}$.

Informacje podawane w źródłach umożliwiają przeanalizowanie liczby urodzeń w badanym okresie.

Wykres 2. Liczba chrztów w Pleszewie w latach 1751-1793

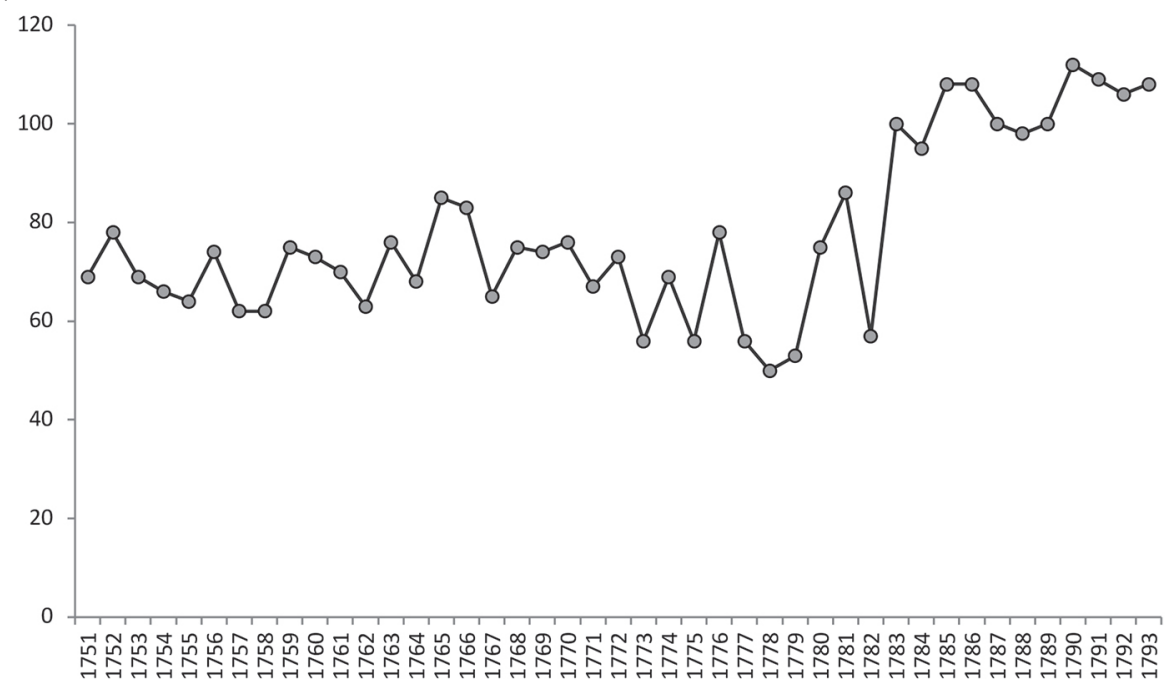

W latach 1751-1793 w Pleszewie zarejestrowano chrzty 3347 dzieci. Okres największej liczby urodzeń to lata 1783-1793. Średnio miesięcznie chrzczono

59 Przepisy kościelne dopuszczały możliwość, iż „w wypadku nagłej potrzeby można udzielić chrztu w każdym miejscu dogodnym" (poza kościołem, niezależnie od pory dnia i nocy). Szafarzem chrztu mógł być zatem każdy człowiek, w razie niebezpieczeństwa śmierci dziecka - ojciec lub matka. W takich wypadkach istniała najprostsza forma chrzcielna ( N. ja cię chrzczę w imię Ojca i Syna i Ducha Świętego ) wypowiedziana w jakimkolwiek języku oraz zwykła woda. Podmiotem chrztu miało być dziecko żywe i już urodzone. Zarządzenia te świadczą o trosce Kościoła, by dzieci nie umierały bez chrztu. Chrzest prywatny w wypadku śmierci niemowlęcia prawdopodobnie nie był rejestrowany w księgach metrykalnych; zob. H. Karbownik, Ofiary iura stolae, s. 47-49.

60 B. Kumor, Przepisy prawne, s. 50-53. 
77 dzieci. Odnotowano 24 przypadki chrztów, podczas których nie zanotowano imienia ani płci dziecka, lub informacje te są nieczytelne. Można przypuszczać, że większość z tych dzieci pochodziła ze związków pozamałżeńskich ${ }^{61}$. Ponadto $\mathrm{w}$ dniu $21 \mathrm{~V} 1769$ r. w Pleszewie odbył się chrzest Żyda (przechrzta), który przeszedł tym samym na wiarę katolicką - jedyna taka sytuacja odnotowana w księgach ${ }^{62}$.

Fot. 1. Chrzest sławetnego Michała Wojciecha, Żyda

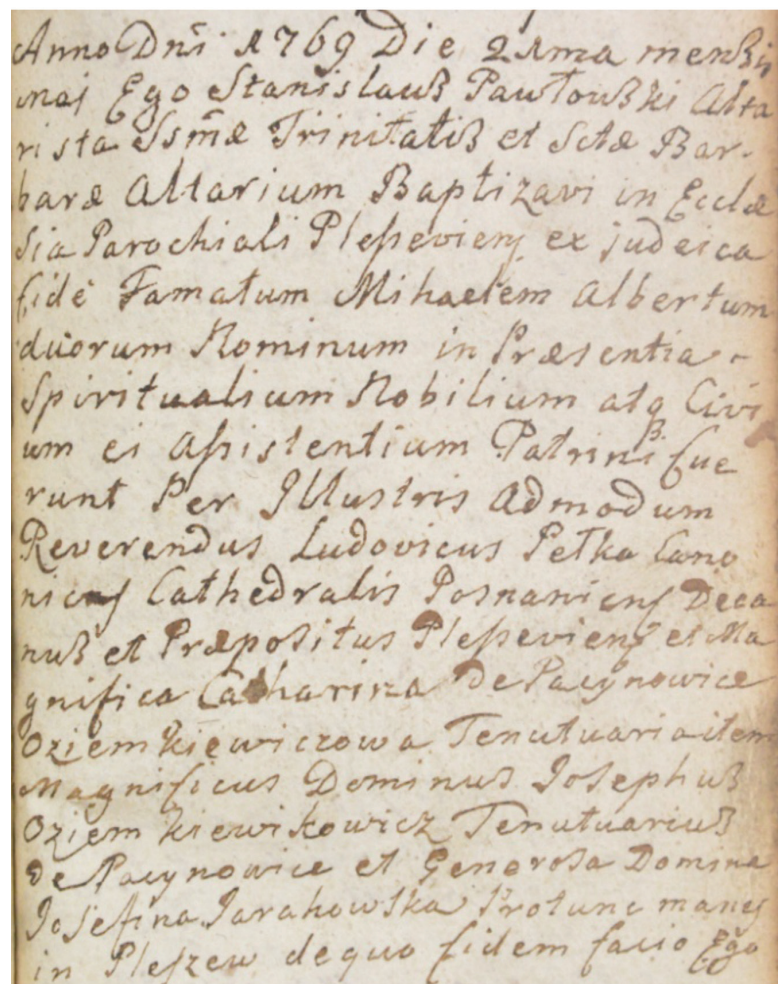

Źródło: AAG, Archiwum parafii Pleszew, 2, k. 161.

Największą liczbę ochrzczonych chłopców odnotowano w latach 1781-1790, natomiast najmniejszą w latach 1771-1780. Najwięcej dziewcząt ochrzczono w latach 1781-1790, zaś najmniej w latach 1771-1780. Według danych z tabeli 7. Najwyższy wskaźnik maskulinizacji ostał odnotowany w latach 1761-1770, zaś najniższy w la-

\footnotetext{
61 Liczba ta nie jest uwzględniana w statystykach.

62 Liber baptisatorum 1743-1782, AAG, Archiwum parafii Pleszew, 2, k. 161.
} 
tach 1751-1760. Wskaźnik maskulinizacji dzieci chrzczonych w całym badanym okresie wynosi 103.

Podczas badania sezonowości miesięcznej urodzeń w parafii pleszewskiej warto zwrócić uwagę na fakt, iż najwięcej dzieci przychodziło na świat w okresie od stycznia do marca, co było konsekwencją kumulacji ślubów w styczniu oraz w lutym. Szczyty poczęć występowały w kwietniu i maju.

Księgi chrztów są źródłem do analizy imion nadawanych dzieciom. Analiza tych danych rzuca światło na mentalność ówczesnych społeczeństw, na panujące w danym czasie mody, trendy oraz praktyki. Wśród imion żeńskich w 2. poł. XVIII w. dominowało imię Marianna, co wynikało z wszechobecnego na ziemiach polskich kultu maryjnego. Pozostałymi najczęstszymi imionami były: Katarzyna, Anna, Agnieszka, Franciszka. Najrzadsze imiona żeńskie to: Petronela, Salomea, Domicela, Gertruda oraz Justyna. Wśród imion męskich dominowały imiona świętych takie jak Jan, Franciszek, Stanisław, Tomasz, Antoni, Jakub, Andrzej, Kasper. Najrzadsze imiona męskie to: Urban, Onufry, Sylwester, Modest, Albin, Jozafat.

Tabela 7. Wskaźnik maskulinizacji dzieci chrzczonych w Pleszewie w latach 1751-1793

\begin{tabular}{|c|c|c|c|}
\hline Lata & Liczba chrztów chłopców $^{\mathrm{a}}$ & Liczba chrztów dziewczą $^{\mathrm{b}}$ & Wskaźnik maskulinizacji $^{\text {L }}$ \\
\hline $1751-1760$ & 329 & 363 & 91 \\
\hline $1761-1770$ & 383 & 352 & 109 \\
\hline $1771-1780$ & 323 & 310 & 104 \\
\hline $1781-1790$ & 515 & 449 & 87 \\
\hline $1791-1793$ & 150 & 173 & 103 \\
\hline Razem & 1700 & 1647 & \\
\hline
\end{tabular}

a AAG, Archiwum parafii Pleszew, 2 (Liber baptisatorum 1743-1782); AAG, Archiwum parafii Pleszew, 3 (Liber baptisatorum 1782-1797).

${ }^{\mathrm{b}}$ AAG, Archiwum parafii Pleszew, 20a (Liber copulatorum 1741-1772); AAG, Archiwum parafii Pleszew, 10 (Liber copulatorum 1772-1796).

Tabela 8. Sezonowość miesięczna urodzeń w Pleszewie w okresie 1751-1793

\begin{tabular}{|c|c|c|c|c|c|c|c|c|c|c|c|c|c|}
\hline \multirow{4}{*}{ Wyszczególnienie } & \multirow{4}{*}{ Ogółem } & \multicolumn{12}{|c|}{ Miesiąc urodzenia } \\
\hline & & $\mathrm{I}$ & II & III & IV & $\mathrm{V}$ & VI & VII & VIII & IX & $\mathrm{X}$ & $\mathrm{XI}$ & XII \\
\hline & & \multicolumn{12}{|c|}{ Miesiąc poczęcia } \\
\hline & & IV & $\mathrm{V}$ & VI & VII & VIII & IX & $\mathrm{X}$ & $\mathrm{XI}$ & XII & I & II & III \\
\hline Liczby bezwzględne & 3347 & 360 & 345 & 344 & 247 & 253 & 231 & 217 & 232 & 245 & 282 & 318 & 273 \\
\hline Wskaźnik sezonowości & 1200 & 127 & 133 & 121 & 90 & 89 & 84 & 76 & 81 & 89 & 99 & 115 & 96 \\
\hline
\end{tabular}

W parafii pleszewskiej najbardziej zamożne rodziny starały się nadawać swoim potomkom nie jedno, lecz więcej imion, czasami nawet trzy różne imiona (np. Juda 
Tadeusz, Ludwik Egidiusz, Albin Kazimierz, Ludwik Joachim Zachariasz, Kasper Melchior Baltazar) ${ }^{63}$, a wszystko w celu podniesienia prestiżu rodziny w lokalnej społeczności. Imiona dwuczłonowe nawiązywały także do osoby konkretnego świętego (np. Stanisław Kostka) ${ }^{64}$.

Fot. 2. Chrzest martwego dziecka w Pleszewie w dniu 6 VI 1766 r.

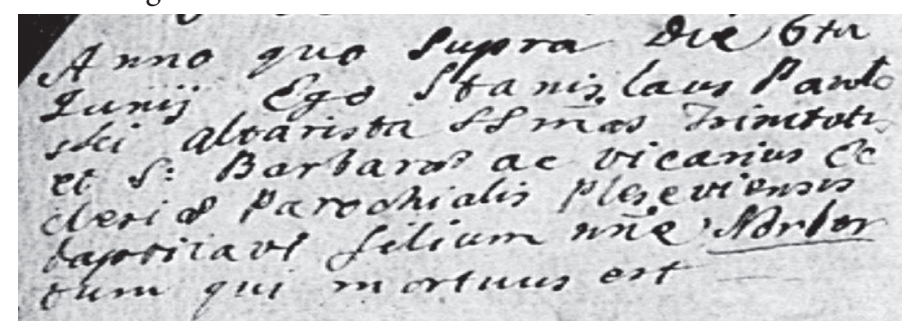

Źródło: AAG, Archiwum parafii Pleszew, 2, k. 140v.

Chrztu udzielano w kościele parafialnym - taka zasada przyjęła się w prawie kanonicznym. Została powtórzona i potwierdzona przez sobór trydencki w XVI w. ${ }^{65}$ Rodzice chrzestni (patrini), przedstawiający do sakramentu osobę chrzczoną, występowali w liczbie dwóch i zawsze była to kobieta i mężczyzna. Bardzo często ojcem chrzestnym był burmistrz miasta Pleszewa. Funkcji tej nie mogli pełnić mąż i żona razem, heretycy, ekskomunikowani i zakonnicy ${ }^{66}$. Rytuat Rzymski z $1614 \mathrm{r}$. zobowiązywał proboszczów, aby nie dopuszczali do nieprzepisowej liczby rodziców chrzestnych oraz dbali, aby tylko osoby godne spełniały tę posługę ${ }^{67}$.

Co dość intrygujące, w pleszewskiej księdze chrztów najprawdopodobniej zarejestrowano chrzest martwego dziecka, który miał miejsce 6 VI 1766 r. Jest to jedyny taki przypadek w analizowanym materiale. Można go interpretować dwojako, jako chrzest martwego dziecka, co byłoby niezwykle dziwne i sprzeczne z doktryną oraz praktyką Kościoła, bądź chrzest umierającego dziecka, które w chwili dokonywania wpisu w księdze już nie żyło - nie da się tego jednoznacznie rozstrzygnąćc8.

63 Istniała tendencja do nadawania dzieciom imienia Kasper lub potrójnego imienia Kasper Melchior Baltazar na początku stycznia, w związku z chrześcijańskim świętem Trzech Króli.

64 J. Hochleitner, Warmińskie nowożytne księgi, s. 151.

65 B. Kumor, Przepisy prawne, s. 42.

66 J. Hochleitner, Warmińskie nowożytne księgi, s. 151.

67 Tenże, s. 142.

68 Anno quo supra, die 6ta Iunii, Ego Stanislaus Pawtowski altarista SS. Trinitatis et S. Barbarae ac 
Na podstawie ksiąg zmarłych zostało zbadane zjawisko zgonów w Pleszewie. Zebrane dane ilustrują poniższe wykresy.

Wykres 3. Liczba zarejestrowanych zgonów ogółem w Pleszewie w latach 1751-1793

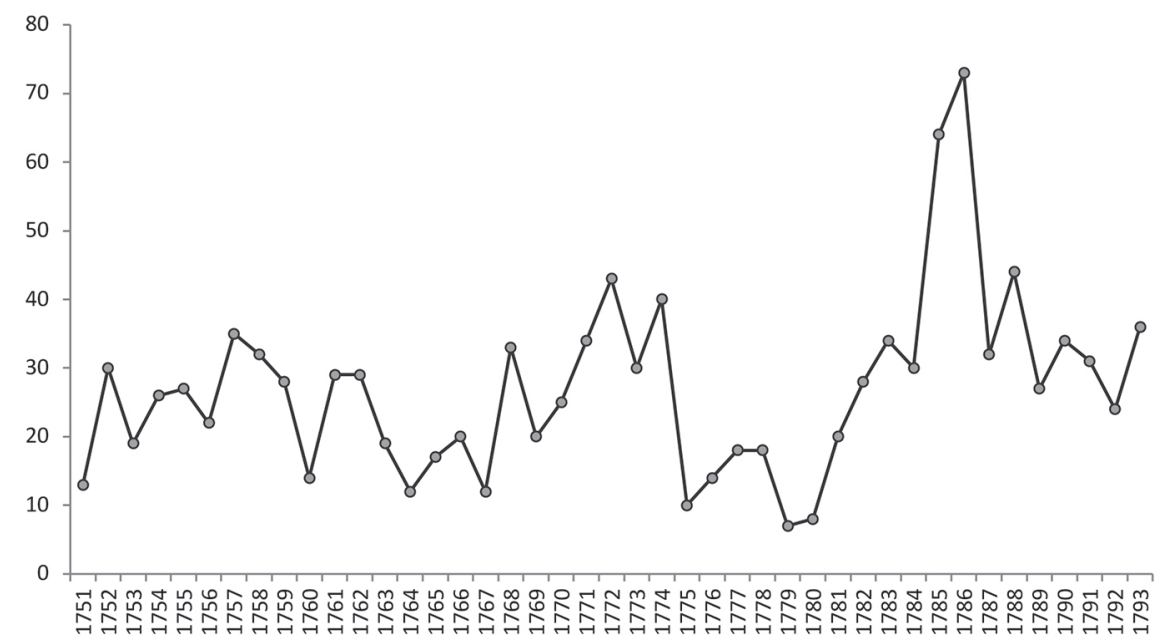

Wykres 4. Liczba zgonów mężczyzn i kobiet w Pleszewie w latach 1751-1793, którzy w chwili zgonu mieli ukończone przynajmniej 10 lat

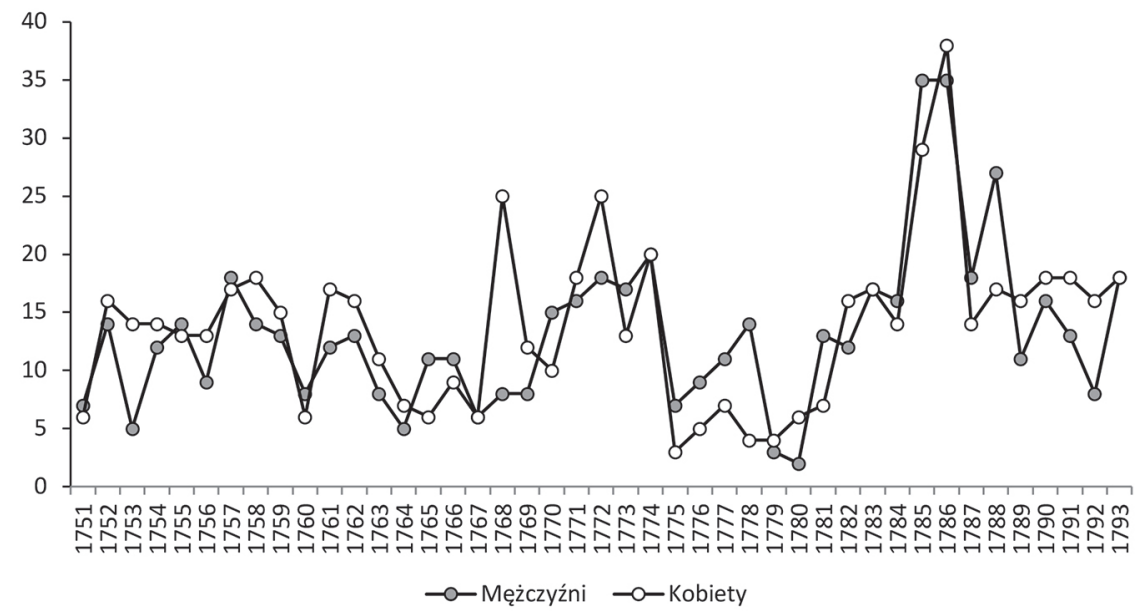

vicarius ecclesiae parochialis Plesseviensis baptisavi filium n [omi]ne Norbertum, qui mortuus est; zob. Liber baptisatorum 1743-1782, AAG, Archiwum parafii Pleszew, 2, k. 140v. 
Wykresy 3 i 4. przedstawiają ogólną liczbę zgonów i w podziale na płeć69. Najwyższa liczba zgonów przypada na lata 1758, 1765, 1768, 1772, 1786 (występują gwałtowne wzrosty), natomiast najniższa na okres od 1775 do 1780 r. Nadmierne wzrosty zgonów znajdują czasem wytłumaczenie w notatkach o zarazach (niekiedy podawano nazwę choroby, która sprowadziła zarazę), jednak w pleszewskich libri mortuorum nie zapisywano takich informacji. Bardziej prawdopodobny jest fakt dokładniejszego prowadzenia ksiąg w tym okresie. Wyraźnie mniejsza liczba zejść w latach 1775-1780 prawdopodobnie ma podłoże rejestracyjne (przerwy w prowadzeniu wpisów bądź niedokładność).

W ciągu badanego okresu najwięcej mężczyzn zmarło w latach 1785, 1786 oraz 1788, natomiast najmniej w 1779 oraz 1780 r. Średnio rocznie umierało 13 mężczyzn. Z powyższego wykresu wynika, iż najwięcej kobiet zmarło w latach 1785 oraz 1786, natomiast najmniej w okresie od 1775 do 1779 . Średnio rocznie umierało 14 kobiet. Proporcje, w jakich kształtowały się liczby zgonów kobiet i mężczyzn, kształtowały się mniej więcej na jednakowym poziomie. W społeczności miejskiej o charakterze rolniczo - rzemieślniczym, mężczyźni pełnili zasadniczą rolę w prowadzeniu gospodarstwa; śmierć głowy rodziny czy syna miała znaczący wpływ na sytuację ekonomiczną rodziny ${ }^{70}$.

W latach 1751-1793 w księgach zmarlych odnotowano łącznie 2114 zgonów ${ }^{71}$, w tym: 567 mężczyzn (26,8\%), 594 kobiety $(28,1 \%)$ oraz 953 dzieci $^{72}(45,1 \%)$. Średnio rocznie umierało 49 osób. Bardzo wysoki był poziom umieralności dzieci ${ }^{73}$. Z powodu niekompletności danych rejestracyjnych, nie można było wyodrębnić zgonów niemowląt. Najwięcej zgonów dzieci w Pleszewie zarejestrowano w latach 1758, 1765 oraz 1768, a najmniej w latach 1776-1780 (prawdopodobieństwo przerwy w rejestracji bądź niedokładności). Średnio rocznie umierało 22 dzieci.

69 Zastosowanie przedziału wiekowego dla mieszkańców poniżej i powyżej 10 roku życia zostało wykorzystane w spisie pruskim; zob. J. Wąsicki, Opisy miast polskich, cz. II, s. 761.

70 K. Korenda, Rejestracja metrykalna, s. 70.

71 Do tej liczby należy dodać 25 osób niezidentyfikowanych, których dane nie zostały zapisane w księgach bądź są nieczytelne. Liczba ta nie jest uwzględniana w statystykach.

72 W pleszewskich księgach zgonów dla dzieci często nie podawano płci. Zaznaczano jedynie, iż jest to parvulus (łac. dziecko).

73 Od 1788 r. zaczęto odnotowywać wiek zmarłych. W Libri mortuorum mieszkańców w przedziale wiekowym poniżej 10 roku życia określano jako infans (łac. niemowlę) lub parvulus (łac. dziecko). Po 10 roku życia nie używano już tych określeń dla zmarłych. 
Wykres 5. Liczba zgonów dzieci w Pleszewie w latach 1751-1793

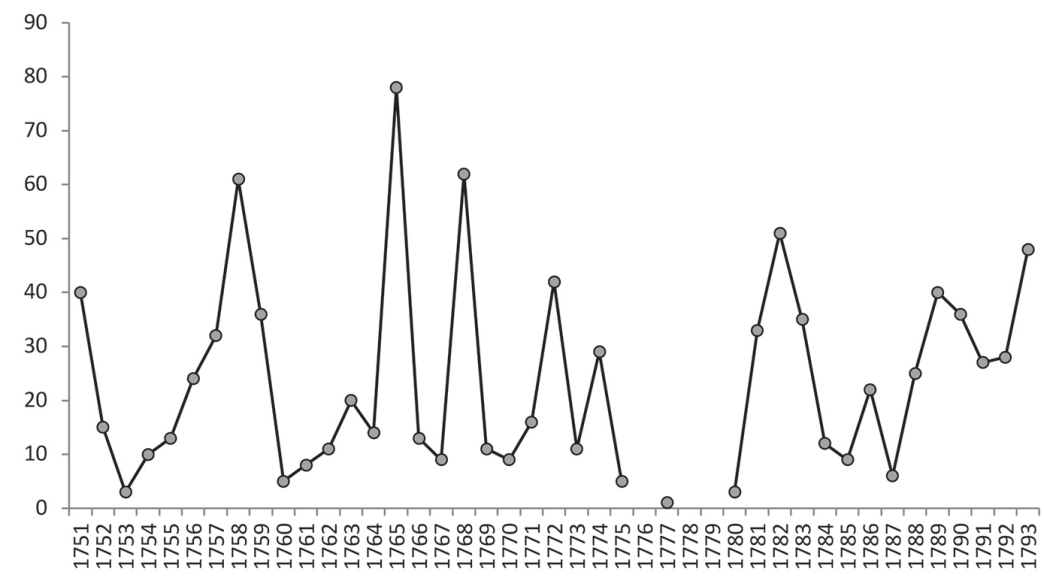

Tabela 9. Sezonowość miesięczna zgonów ogółem w parafii Pleszew w latach 1751-1793

\begin{tabular}{|c|c|c|c|c|c|c|c|c|c|c|c|c|c|}
\hline \multirow{2}{*}{ Wyszczególnienie } & \multirow{2}{*}{ Ogólem } & \multicolumn{12}{|c|}{ Miesiąc zgonu } \\
\hline & & I & II & III & IV & $\mathrm{V}$ & VI & VII & VIII & IX & $\mathrm{X}$ & XI & XII \\
\hline Liczby bezwzględne & 2114 & 181 & 171 & 205 & 219 & 187 & 186 & 210 & 204 & 165 & 139 & 119 & 128 \\
\hline Wskaźnik sezonowości & 1200 & 101 & 105 & 114 & 126 & 104 & 107 & 117 & 114 & 95 & 77 & 69 & 71 \\
\hline
\end{tabular}

Tabela 10. Sezonowość miesięczna zgonów ogółem w parafii Pleszew w latach 1751-1772

\begin{tabular}{|c|c|c|c|c|c|c|c|c|c|c|c|c|c|}
\hline \multirow{2}{*}{ Wyszczególnienie } & \multirow{2}{*}{ Ogółem } & \multicolumn{12}{|c|}{ Miesiąc zgonu } \\
\hline & & I & II & III & IV & $\mathrm{V}$ & VI & VII & VIII & IX & $\mathrm{X}$ & $\mathrm{XI}$ & XII \\
\hline Liczby bezwzględne & 1074 & 97 & 95 & 117 & 126 & 91 & 105 & 87 & 91 & 74 & 73 & 56 & 62 \\
\hline Wskaźnik sezonowości & 1200 & 106 & 114 & 128 & 143 & 100 & 119 & 95 & 100 & 84 & 80 & 63 & 68 \\
\hline
\end{tabular}

Tabela 11. Sezonowość miesięczna zgonów ogółem w parafii Pleszew w latach 1772-1793

\begin{tabular}{|c|c|c|c|c|c|c|c|c|c|c|c|c|c|}
\hline \multirow{2}{*}{ Wyszczególnienie } & \multirow{2}{*}{ Ogółem } & \multicolumn{12}{|c|}{ Miesiąc zgonu } \\
\hline & & I & II & III & IV & $\mathrm{V}$ & VI & VII & VIII & IX & $\mathrm{X}$ & $\mathrm{XI}$ & XII \\
\hline Liczby bezwzględne & 1040 & 84 & 76 & 88 & 93 & 96 & 81 & 123 & 113 & 91 & 66 & 63 & 66 \\
\hline Wskaźnik sezonowości & 1200 & 95 & 95 & 100 & 109 & 109 & 95 & 139 & 128 & 106 & 75 & 74 & 75 \\
\hline
\end{tabular}

Kumulacja zjawiska zgonów występowała w okresie przednówka (marzec-kwiecień). Najwięcej parafian zmarło w miesiącach wiosennych, kiedy zapasy żywności były na wyczerpaniu, a organizm ludzki osłabiony głodem był wyraźnie słabszy i bardziej podatny na choroby, co przy ogólnie niskim poziomie medycyny powodowało przedwczesne zejścia. Liczba zgonów w okresie przednówka spadła w latach 1772 -1793. W tym okresie miesiącami o najwyższej liczbie zgonów były lipiec i sierpień. 
W Libri mortuorum rejestrowano następujące dane: imię i nazwisko zmarłego (w przypadku dziecka - tylko imię oraz rodziców), imię i nazwisko kapłana odprawiającego pogrzeb, data i miejsce ceremonii, zawód (np. sutor, archimagister, organarius, molitor, sartor), predykat stanowy. Nie rejestrowano daty śmierci, więc trudno jednoznacznie stwierdzić, jaki był odstęp czasu między zgonem a pogrzebem. Miejsce pochówku na przykościelnym cmentarzu zarejestrowano trzykrotnie w ciągu badanego okresu, a opis położenia wskazywano względem plebanii, np. (...) depositum est corpus eius ante ianuam in medii Ecclesiae oppositam domui plebanali ${ }^{74}$, szkoły parafialnej, np. (...) eius corpus depositum est ante fenestrum scholae iuventutis Plesseviensis ${ }^{75}$, a także ołtarza, np. (...) in coemeterio post Maius altare ${ }^{76}$.

Tabela 12. Natężenie zgonów w Pleszewie w latach 1771, 1789 i 1793

\begin{tabular}{|c|c|c|}
\hline Rok & Liczba ludności & Współczynnik zgonów \\
\hline 1771 & 1000 & 50,0 \\
\hline 1789 & 1509 & 44,4 \\
\hline 1793 & 1254 & $67,0^{\mathrm{a}}$ \\
\hline
\end{tabular}

${ }^{a}$ Uwagę zwraca współczynnik zgonów dla 1793 r. Jest jednak prawdopodobny z powodu wartości badawczej źródeł, z których zaczerpnięto dane: liczba ludności w tym okresie pochodzi ze spisu pruskiego, w którym władze skrupulatnie odnotowywały informacje, a liczba zgonów z księgi metrykalnej.

Tabela 13. Liczba zgonów dzieci na 100 urodzeń w Pleszewie w latach 1751-1793

\begin{tabular}{|c|c|c|c|}
\hline Badany okres & Średnia liczba zgonów dzieci (1) & Średnia liczba urodzeń (2) & Stosunek zgonów do urodzeń \\
\hline $1751-1760$ & 23,9 & 69,2 & 34,5 \\
\hline $1761-1770$ & 23,5 & 73,5 & 31,0 \\
\hline $1771-1780$ & 10,7 & 63,3 & 16,9 \\
\hline $1781-1790$ & 26,9 & 96,4 & 27,9 \\
\hline $1791-1793$ & 34,3 & 107,7 & 31,9 \\
\hline
\end{tabular}

Księga zmarłych zawiera interesujące notatki umieszczone na marginesach przy zapisie zgonu zwłaszcza ważniejszych osobistości. Na przykład dnia 21 VII 1756 r. zmarł Andrzej Śniegocki, mieszczanin pleszewski, który pełnił urząd ławnika w magistracie miejskim ${ }^{77}$. Dnia 12 XI 1766 r. odbyły się uroczystości pogrzebowe burmistrza Marcina Jezierskiego ${ }^{78}$. Tego rodzaju notatki świadczą o religijności, postawie życiowej a zarazem o kulturze mieszczan pleszewskich.

\footnotetext{
74 Liber mortuorum 1735-1772, AAG, Archiwum parafii Pleszew, 15, k. 29.

75 Tamże, k. 29-29v.

76 Tamże, k. 22v-23.

77 Tamże, k. 32-32v.

78 Tamże, k. 52v.
} 
Zmarłych w wieku niemowlęcym lub dziecięcym określano jako infans lub parvulus, w wieku młodzieńczym: iuvenis, virgo lub adolescens, w wieku dojrzałym stosowano predykat wynikający z przynależności stanowej, np. famatus, laboriosus, natomiast mieszkańców zmarłych w wieku podeszłym określano jako senex.

Fot. 3. Chrzest Ludwiki, córki Marianny i Ignacego Koźmińskich, właścicieli Pleszewa - fragment wpisu do księgi

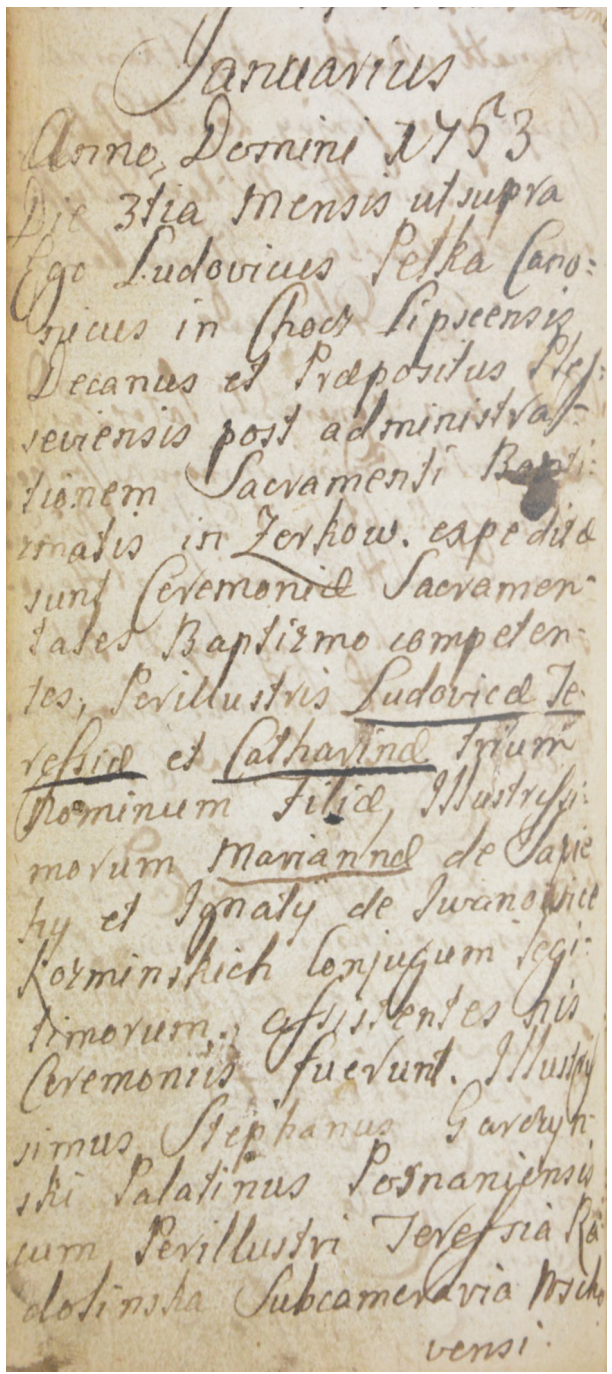

Źródło: AAG, Archiwum parafii Pleszew, 2, k. 54v. 
Od 1788 r. zauważa się w pleszewskich księgach metrykalnych odnotowywanie wieku zmarłych. Wiek osób dorosłych zapisywano w latach, a dzieci także w miesiącach, a nawet dniach ${ }^{79}$.

Z powodu ówczesnych warunków sanitarno-higienicznych, liczba zgonów dzieci kształtowała się wysoko. Informacje o osobach trudniących się medycyną w Pleszewie, które niewątpliwie miały wpływ na obniżenie umieralności mieszkańców, spotykamy dopiero pod koniec omawianego okresu ${ }^{80}$. Średnia wartość stosunku zgonów do urodzeń dla omawianego okresu wynosi $28,6 \%$, co może oznaczać, że prawie co trzecie dziecko umierało nie doczekawszy wejścia w okres nastoletni.

Głównym przedmiotem niniejszego artykułu była analiza ruchu naturalnego ludności Pleszewa w latach 1751-1793. Średnia liczba urodzeń w ciągu roku wyniosła 82,0, średnia liczba małżeństw 15,9, natomiast średnia liczba zgonów 51,5. Obliczony współczynnik U/M wyniósł 5,2, zaś współczynnik U/Zg 1,6. Zaprezentowano również i poddano weryfikacji wartość badawczą ksiąg metrykalnych parafii pleszewskiej. Prowadzone były w sposób staranny i czytelny, bardzo rzadko występują nieczytelne zapisy. Zauważono także częste zmiany pisma, a także krótkie przerwy w prowadzeniu rejestracji. Podczas badania małżeństw omówiony został zasięg terytorialny doboru nowożeńców, który wykazał, że do Pleszewa częściej migrowali mężczyźni niż kobiety, a nowożeńcy najczęściej napływali z miejscowości w obrębie $40 \mathrm{~km}$. Najwięcej ślubów zawierano w styczniu oraz w lutym, najmniej - w marcu i kwietniu. W Pleszewie średnio chrzczono 77 dzieci rocznie, a wskaźnik maskulinizacji dzieci chrzczonych wyniósł 103. Najwięcej dzieci rodziło się od stycznia do marca, najmniej - od czerwca do września. Poruszony został problem dotyczący nadawania imion dzieciom. Wśród imion żeńskich dominowało imię Marianna, Katarzyna oraz Anna, natomiast wśród męskich: Jan, Franciszek, oraz Stanisław. Omówiono zgony mężczyzn, kobiet oraz mieszkańców Pleszewa poniżej 10 roku życia. Sezonowość miesięczna zgonów wykazała, że w latach 1772-1793 spadła umieralność w okresie przednówka. Największą liczbę zarejestrowanych zgonów odnotowano w lipcu i sierpniu. Podjęta została

\footnotetext{
79 Liber mortuorum 1772-1796, AAG, Archiwum parafii Pleszew, 10, k. 21, 25.

80 Wildygans (Dzikagęś) - aptekarz (1788 r.); zob. Liber actorum et variarum transactionum comparatus per famatum Joannem Szopniewski advocatum Plesseviensem, anno Domini 1775, Archiwum Państwowe w Poznaniu, (dalej APP), Akta miasta Pleszew 1428-1805, I/38, s. 225-226; Jan Bittner - doktor (1788 r.); zob. tamże, s. 225-226; Franciszek Olkowski - felczer, chirurg polowy (1793 r.); zob. Liber actorum et variarum transactionum per famatum ac spectabilem Stanislaum Kozłowicz advocatum Plesseviensem, sub notariatu domini Antonii Zarnowski comparatus die 21 mensis ianuarii 1789, APP, Akta miasta Pleszew 1428-1805, I/39, s. 195-196.
} 
również próba przedstawienia losów demograficznych kilku rodzin pleszewskich, która wykazała, że średni odstęp czasu między narodzinami dzieci wynosił dwa lata, oczywiście z uwagi na niewielką grupę poddaną analizie, ustalenia te nie mogą dawać wniosków dla całości populacji pleszewskiej. Praca ta stanowi przyczynek do dalszych badań demograficznych nad ludnością Pleszewa w XVIII w.

Nadesłany: 15 II 2018

Nadesłany po poprawkach recenzyjnych: 15 III 2018

Zaakceptowany: 18 III 2018

\author{
mgr Artur Makowski \\ Instytut Historii \\ Wydział Historyczny \\ Uniwersytet im. Adama Mickiewicza w Poznaniu \\ ul. Umultowska 89d \\ 61-614 Poznań \\ ludwik6667@poczta.onet.pl
}

\title{
The population of Pleszew in the years 1751-1793 in the light of birth certificate registers
}

The article presents the vital statistics of the population of the town of Pleszew in 1751-1793. The source materials were birth certificate registers from Pleszew parish and city records. In order to analyze the collected material it was imperative to assess the value of the research sources. The results indicate that the birth certificate registers were carefully maintained and in accordance with the prevailing rules but with short breaks in the registration. An analysis of marriages has shown that the most popular months for concluding this sacrament were January and February. The article also discusses the influx of German population in the vicinity of Pleszew and its consequences. The author draws attention to the accumulation of marriage vows in January and February, the consequence of which was the highest number of births between January and March. Comments are provided on the issue of naming. The mortality rate in the population has been analyzed.

This article attempts to present the fate of selected Pleszew families in order to prove that vital records also allow to reconstruct family trees. To further study this issue, however, the scope of the source needs to be broadened. 